Abstracta Iranica Abstracta Iranica

Revue bibliographique pour le domaine irano-aryen

Volume 30 | 2010

Comptes rendus des publications de 2007

\title{
«The Tyrian Monetary Inscriptions of the Persian Period ». Transeuphratène, 34, 2007, pp. 65-101.
}

\section{Astrid Nunn}

\section{(2) OpenEdition}

1 Journals

\section{Édition électronique}

URL : http://journals.openedition.org/abstractairanica/37632

DOI : 10.4000/abstractairanica.37632

ISSN : 1961-960X

Éditeur :

CNRS (UMR 7528 Mondes iraniens et indiens), Éditions de l'IFRI

\section{Édition imprimée}

Date de publication : 8 avril 2010

ISSN : 0240-8910

\section{Référence électronique}

Astrid Nunn, " "The Tyrian Monetary Inscriptions of the Persian Period ». Transeuphratène, 34, 2007, pp. 65-101. », Abstracta Iranica [En ligne], Volume 30 | 2010, document 66, mis en ligne le 08 avril 2010, consulté le 26 septembre 2020. URL : http://journals.openedition.org/abstractairanica/37632 ; DOI : https://doi.org/10.4000/abstractairanica.37632

Ce document a été généré automatiquement le 26 septembre 2020.

Tous droits réservés 


\section{«The Tyrian Monetary Inscriptions} of the Persian Period ».

\section{Transeuphratène, 34, 2007, pp. 65-101.}

\section{Astrid Nunn}

1 Les monnaies tyriennes de l'époque achéménide sont rarement inscrites, leurs inscriptions en deviennent d'autant plus intéressantes. Elles comprennent les légendes des ateliers émetteurs (mesures, poids, noms royaux), des contremarques officielles ou privées et des graffitis de nature privée (noms de personne). Ces inscriptions permettent de reconstituer aussi bien la paléographie tyrienne que certains aspects socioculturels de la vie tyrienne. Ainsi, il semble qu'une bonne partie de la population était alphabétisée.

INDEX

Thèmes : 3.2.2. Pré-Achéménides et Achéménides

\section{AUTEUR}

ASTRID NUNN

J. Elayi 